\title{
Long-term change and variation of salinity in the western North Pacific subtropical gyre revealed by 50-year long observations along $137^{\circ} \mathrm{E}$
}

\author{
Eitarou Oka $^{1} \cdot$ Shota Katsura $^{1} \cdot$ Hiroyuki Inoue $^{2} \cdot$ Atsushi Kojima $^{2,3}$. \\ Moeko Kitamoto $^{2,3} \cdot$ Toshiya Nakano $^{2,3} \cdot$ Toshio Suga $^{4,5}$
}

Received: 20 December 2016 / Revised: 9 February 2017 / Accepted: 12 February 2017 / Published online: 23 February 2017

(c) The Author(s) 2017. This article is published with open access at Springerlink.com

\begin{abstract}
The $137^{\circ} \mathrm{E}$ repeat hydrographic section for 50 winters during 1967-2016 has been analyzed to examine interannual to interdecadal variations and long-term changes of salinity and temperature in the surface and intermediate layers of the western North Pacific, with a particular focus on freshening in the subtropical gyre. Rapid freshening on both isobars and isopycnals began in the mid-1990s and persisted for the last 20 years in the upper main thermocline/halocline in the western subtropical gyre. In addition, significant decadal variability of salinity existed in the subtropical mode water (STMW), as previously reported for the shallower layers. An analysis of the $144^{\circ} \mathrm{E}$ repeat hydrographic section during 1984-2013 supplemented by Argo profiling float data in 2014 and 2015 revealed that the freshening trend and decadal variability observed at $137^{\circ} \mathrm{E}$ originated in the winter mixed layer in the Kuroshio Extension (KE) region and was transmitted southwestward to $137^{\circ} \mathrm{E} 1-2$ years later in association with the subduction and advection of STMW. The mechanism of these changes and variations in the source region
\end{abstract}

Eitarou Oka

eoka@aori.u-tokyo.ac.jp

1 Atmosphere and Ocean Research Institute, The University of Tokyo, Kashiwa 277-8564, Japan

2 Global Environment and Marine Department, Japan Meteorological Agency, Tokyo 100-8122, Japan

3 Oceanography and Geochemistry Research Department, Meteorological Research Institute, Tsukuba 305-0052, Japan

4 Department of Geophysics, Graduate School of Science, Tohoku University, Sendai 980-8578, Japan

5 Research and Development Center for Global Change, Japan Agency for Marine-Earth Science and Technology, Yokosuka 237-0061, Japan was further investigated. In addition to the surface freshwater flux in the KE region pointed out by previous studies, the decadal KE variability in association with the Pacific Decadal Oscillation likely contributes to the decadal salinity variability through water exchange between the subtropics and the subarctic across the KE. Interdecadal change in both the surface freshwater flux and the KE state, however, failed to explain the rapid freshening for the last 20 years.

Keywords Western North Pacific subtropical gyre - Main thermocline/halocline $\cdot$ Long-term change $\cdot$ Decadal variability $\cdot$ Repeat hydrographic section

\section{Introduction}

Long-term changes of salinity in the surface and intermediate layers of the world oceans have been investigated on the basis of repeat hydrography, historical data archives, and the Argo profiling float network (e.g., Wong et al. 1999; Boyer et al. 2005; Hosoda et al. 2009; Durack and Wijffels 2010) to detect intensification of salinity contrast between regions/basins suggesting that of the global hydrological cycle (Rhein et al. 2013). In the North Pacific subtropical gyre, both isobaric and isopycnal freshening has been widely observed in the main thermocline/halocline as well as the underlying salinity minimum layers of the North Pacific Intermediate Water (NPIW; Reid 1965) and the Tropical Salinity Minimum (TSM; Yuan and Talley 1992), and has been attributed to surface freshening and warming in the formation areas of these water masses and to the change of gyre circulation (Lukas 2001; Wong et al. 2001; Nakano et al. 2007; Ren and Riser 2010; Suzuki and Ishii 2011; Yan et al. 2013; Nan et al. 2015). 


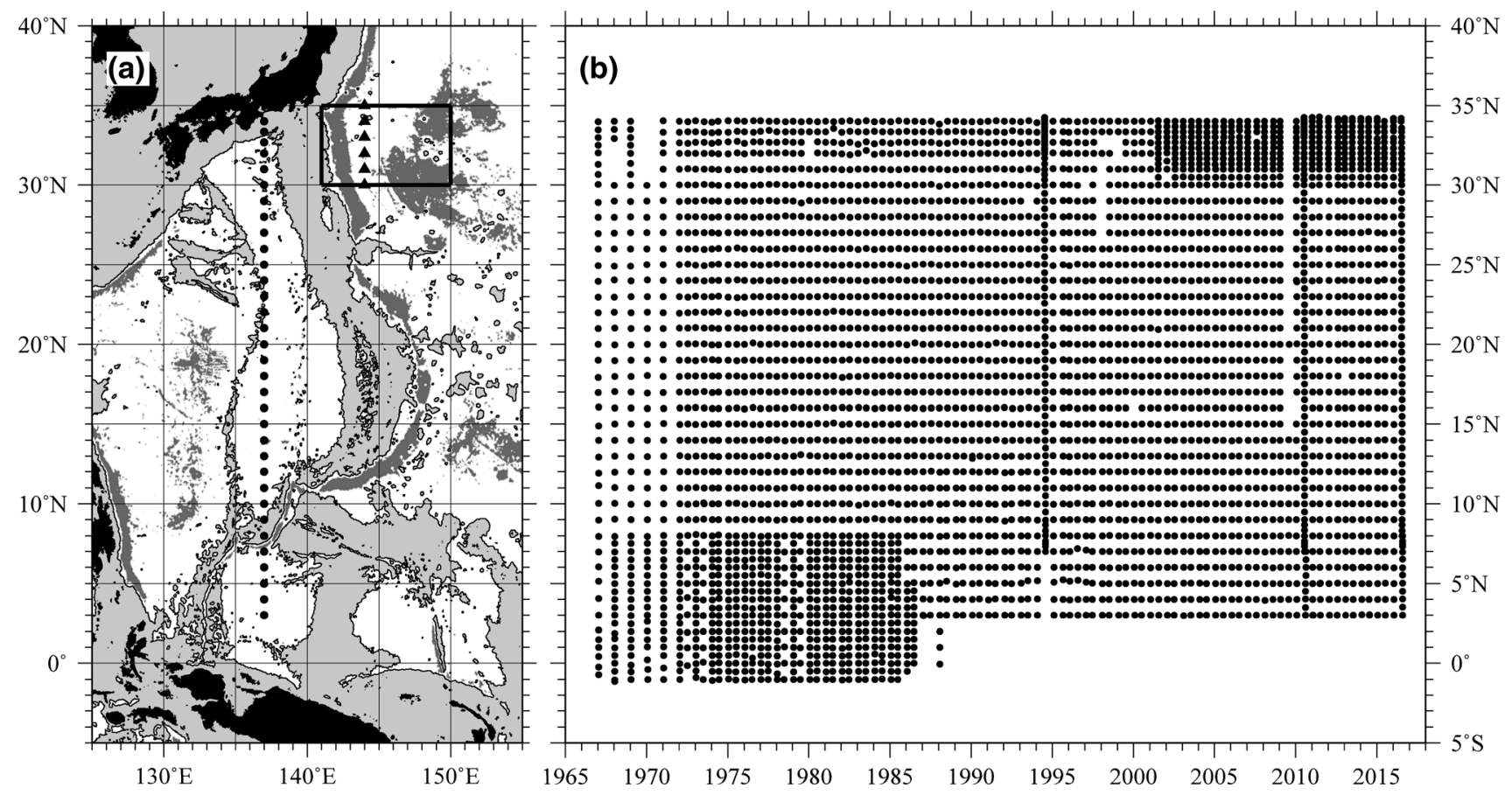

Fig. 1 a Geographical location of the $137^{\circ} \mathrm{E}$ section. Dots indicate grid points for optimal interpolation (Sect. 2). Light (dark) shading denotes regions shallower (deeper) than $4000 \mathrm{~m}(6000 \mathrm{~m})$. Triangles indicate the location of CTD and expendable CTD stations at the

The rate and depths of observed freshening depend heavily on the period. When we compare the linear trend of isobaric salinity during 1967-2005 (Fig. 2a in Nakano et al. 2007) and that during 1992-2009 (Fig. 4c in Nan et al. 2015), both based on the repeat hydrographic section along the $137^{\circ} \mathrm{E}$ meridian, a freshening trend reaching -0.0015 (on the Practical Salinity Scale 1978) year ${ }^{-1}$ existed from the lower main halocline to NPIW/TSM during the former period, while the freshening trend was several times larger in magnitude and was located from the upper main halocline to the sea surface during the latter, more recent period. Such a difference suggests significant interdecadal variability and raises the following questions. How have the rate and depths of freshening in the North Pacific subtropical gyre changed over time? Has the freshening trend been accelerating in recent years? What water masses have played an important role for the recent rapid changes?

To answer these questions, long-term repeat observations at a fixed station or along a fixed line are indispensable. The aforementioned $137^{\circ} \mathrm{E}$ section traversing the western North Pacific (Masuzawa 1967; Fig. 1a) is the most appropriate one for such a purpose, achieving an unprecedented history of a half century in 2016. In this study, we analyze an extended time series of the $137^{\circ} \mathrm{E}$ section for 50 years from 1967 through 2016 to examine interannual to interdecadal variations and long-term changes of salinity $144^{\circ} \mathrm{E}$ section used in Sect. 4. Thick lines represent the area in which $E-P$ was averaged in Fig. 6c. b Latitude of observations at the $137^{\circ} \mathrm{E}$ section, plotted against year. Note that the data from summer observations were not used in this study

and temperature in the surface and intermediate layers, with a particular focus on freshening in the subtropical gyre. By also using another repeat hydrographic section at $144^{\circ} \mathrm{E}$, we will demonstrate that rapid freshening began in the mid1990s and persisted for the last 20 years in the upper main halocline as a result of surface freshening in the KE region.

\section{Data}

Hydrographic observations at the $137^{\circ} \mathrm{E}$ section have been repeated every winter since 1967 and every summer since 1972 by the Japan Meteorological Agency (Masuzawa and Nagasaka 1975; Fig. 1b). The observations were conducted from $34^{\circ} \mathrm{N}$ to $1^{\circ} \mathrm{S}$ in earlier years, but have been limited to north of $3^{\circ} \mathrm{N}$ since winter 1987 . The typical station spacing is $1^{\circ}$ in latitude, except for $0.67^{\circ}$ at $32-34^{\circ} \mathrm{N}$. The collected data are publicly available online (http://www.data. jma.go.jp/gmd/kaiyou/db/vessel_obs/data-report/html/ship/ ship_e.php).

In this study, we used salinity $(S)$ and temperature $(T)$ data from 50 winter cruises in 1967-2016 because the winter observations have been repeated exactly in the latter half of January from the southern coast of Japan toward New Guinea and also because we liked to remove the influence of seasonal variations on our isobaric and isopycnal 
analyses. We optimally interpolated $S$ and $T$ between $3^{\circ}$ and $34^{\circ} \mathrm{N}$ from each cruise onto grid points at every $1^{\circ}$ (except for $0.67^{\circ}$ at $32-34^{\circ} \mathrm{N}$ ) meridional and 1 dbar vertical interval following Nakano et al. (2007) (Fig. 1a) and calculated potential temperature $(\theta)$ and density $\left(\sigma_{\theta}\right)$. It should be mentioned that the change of observation system in 1990, that is, switch from observations at standard depths by Nansen bottles to continuous measurements by a conductivity-temperature-depth profiler (CTD; Shuto 1996), does not affect the conclusions of this study. The measurement accuracy of $S(T)$ has improved from $0.003\left(0.004{ }^{\circ} \mathrm{C}\right)$ to $0.001\left(0.002{ }^{\circ} \mathrm{C}\right)$ (Japan Meteorological Agency 1970 ; Talley et al. 2011), but even the earlier accuracy was sufficiently small compared to the observed variations and changes shown in the following sections (e.g., Fig. 3). As for the change in vertical sampling resolution, we made another dataset for 1990-2016 by extracting $S$ and $T$ values at the standard depths from the CTD data and combined it with the original data in 1967-1989 to obtain almost the same results (not shown).

We also used $S$ and $T$ data at a repeat hydrographic section along $144^{\circ} \mathrm{E}$ maintained by the Japan Coast Guard (its English name was the Japan Maritime Safety Agency before 2001) from 1984 through 2013. The observations were repeated every winter (mostly in February) using $\mathrm{CTD}$ and expendable CTD between $1^{\circ} \mathrm{S}$ and $35^{\circ} \mathrm{N}$ (Suga et al. 2000). Data after 1996 were downloaded online (http://www1.kaiho.mlit.go.jp/KANKYO/KAIYO/rep_obs/ rep_obs.html), and those before 1995 were extracted from Japan Maritime Safety Agency (1986-1996). In addition, we used evaporation data from the Objectively Analyzed air-sea Fluxes (OAFlux) project (Yu and Weller 2007; Yu et al. 2008) and precipitation data from the Climate Prediction Center Merged Analysis of Precipitation (CMAP; Xie and Arkin 1996, 1997) and the Global Precipitation Climatology Project (GPCP; Huffman et al. 1997; Adler et al. 2003) during 1986-2014.

\section{Long-term thermohaline variations and changes at $137^{\circ} \mathrm{E}$}

The linear trend of $\theta$ for 50 years (1967-2016) obtained by the least-squares method was positive at the sea surface throughout the $137^{\circ} \mathrm{E}$ section and exceeded $0.03{ }^{\circ} \mathrm{C}$ year ${ }^{-1}$ in two subsurface regions: $100-200 \mathrm{dbar}$ at $8-17^{\circ} \mathrm{N}$ and $150-650 \mathrm{dbar}$ at $30-33^{\circ} \mathrm{N}$ (Fig. 2a). The $S$ trend was also positive in these regions, while it was mostly negative in the other part of the section and exceeds -0.001 year $^{-1}$ at $100-600$ dbar and $19-28^{\circ} \mathrm{N}$ (Fig. 2b). This large negative trend in the subtropical gyre, which was significant at the 95\% confidence level, is shallower than that during 19672005 located mainly at $400-800$ dbar (Fig. 2a in Nakano et al. 2007) and is a little deeper than that during 1992 2009 located between the sea surface and 600 dbar (Fig. 4c in Nan et al. 2015).

To examine the relation between trends and temporal variations, $\theta$ and $S$ were averaged in three regions characterized by large trends (green boxes in Fig. 2a, b). In the first region at $100-200 \mathrm{dbar}$ and $8-17^{\circ} \mathrm{N}$, which corresponds to the upper permanent thermocline in the strong portion of the North Equatorial Current (NEC; e.g., Qiu and Joyce 1992), $\theta$ changed interannually and was high (low) during La Niña (El Niño) periods (Fig. 3a; $\theta$ anomalies from the low-pass filtered values were negatively correlated with 5-month running mean of the Niño-3 index with a coefficient $R=-0.69$ ), as demonstrated by previous analyses (e.g., Shuto 1996). It also showed a longterm increase after the mid-1990s, which is consistent with the southward shift of NEC detected by satellite altimeter measurements since 1992 (Qiu and Chen 2012). $S$ in this region (Fig. 2b), which includes the most saline portion $(S>35)$ of the North Pacific Tropical Water (NPTW; Cannon 1966; Tsuchiya 1968) subducted from the central part of the subtropical gyre (Katsura et al. 2013), reflected not only the El Niño-Southern Oscillation state and the southward shift of NEC but also the long-term variation of NPTW (Saiki 1987; Suga et al. 2000; Fig. 3b). Its variation resembles well that in the area of NPTW south of $18^{\circ} \mathrm{N}$ in the $137^{\circ} \mathrm{E}$ section (Fig. $4 \mathrm{c}$ in Nakano et al. 2015).

The Kuroshio usually crosses the $137^{\circ} \mathrm{E}$ section near $33^{\circ} \mathrm{N}$ close to the southern coast of Japan, but occasionally shifts offshore as far south as $30^{\circ} \mathrm{N}$ (Qiu and Joyce 1992). Such a large meander state, which persists for several months to several years, frequently occurred during 1975-1991 and has hardly occurred since then (Kawabe 1995; Usui et al. 2013). $\theta$ and $S$ in the second region at $200-500$ dbar and $30-32.67^{\circ} \mathrm{N}$ concurrently dropped during large-meander periods (Fig. 3c, d) and showed an increasing trend (Fig. 2a, b) due to interdecadal change of large-meander occurrence (Fig. 3c, d).

In the third region at $200-500 \mathrm{dbar}$ and $19-28^{\circ} \mathrm{N}$ in the subtropical halocline (Fig. 2b), which is the region of our interest, $\theta$ and $S$ were highly correlated with each other on interannual time scales (Fig. 3e, f; $R=0.82$ between anomalies from the low-pass filtered values), presumably associated with isopycnal depth variations, but were negatively correlated on interdecadal time scales $(R=-0.40$ between the low-pass filtered values). On interdecadal time scales, both $\theta$ and $S$ gradually increased until around 1990, largely because of anomalously low values in 1973 under a strong El Niño condition (Masuzawa and Nagasaka 1975); subsequently, $\theta$ changed little, while $S$ decreased significantly, particularly after the yearly values reached a pronounced maximum in 1997 . When we divide the 50-year observation period into the former 30 years (1967-1996) 
Fig. 2 Average (black contour; units ${ }^{\circ} \mathrm{C}$ in a) and linear trend (white contours with color; units ${ }^{\circ} \mathrm{C}$ year ${ }^{-1}$ in $\mathbf{a}$ and year ${ }^{-1}$ in $\mathbf{b})$ of $\mathbf{a} \theta$ and $\mathbf{b} S$ with respect to pressure in the $137^{\circ} \mathrm{E}$ section during 1967-2016. Crosses (dots) indicate regions where the linear trend is insignificant at the $90 \%$ (95\%) confidence level. Green rectangles denote the regions where $\theta$ and $S$ are averaged in Fig. 3. Linear trend of $S$ during c 1967-1996 and d 1997-2016, otherwise following $\mathbf{b}$
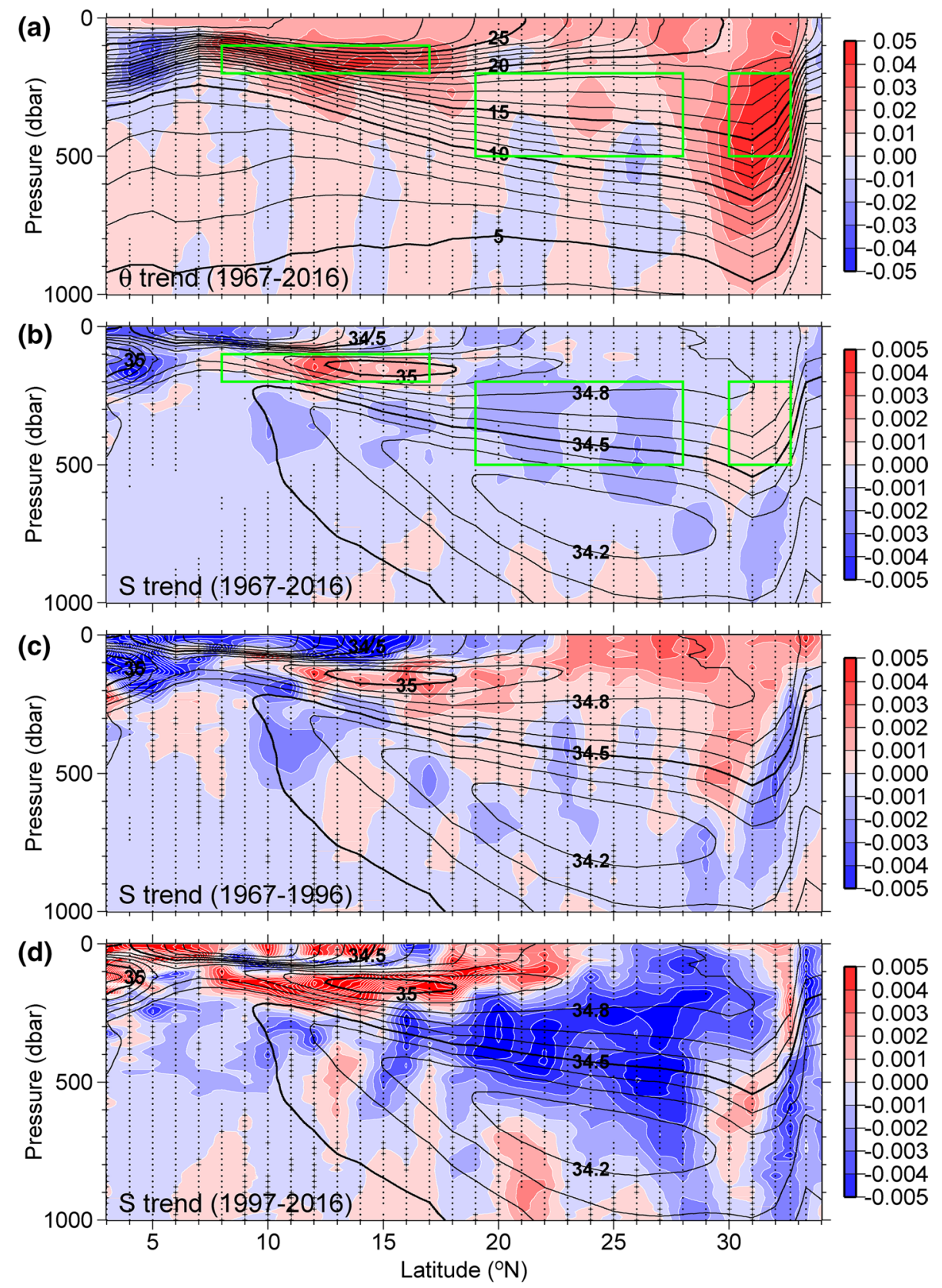

and the latter 20 years (1997-2016) before and after the maximum, the $S$ trend in the subtropical halocline for the former period was small with a magnitude mostly less than 0.001 year $^{-1}$ (Fig. 2c), while that for the latter period was strongly negative with a minimum of -0.0064 year $^{-1}$ located at $420 \mathrm{dbar}, 22^{\circ} \mathrm{N}$ (Fig. 2d).

The freshening trend and the associated $S$ variations in the subtropics are further examined on the $\sigma_{\theta}$ coordinate to obtain more robust signals unaffected by isopycnal depth variations. The isopycnal $S$ trend for 50 years was negative below the most saline portion of NPTW and exceeded -0.002 year $^{-1}$ at $\sigma_{\theta}=25.2-26.0 \mathrm{~kg} \mathrm{~m}^{-3}$ north of $14^{\circ} \mathrm{N}$ corresponding to the upper main halocline (Fig. 4a). By dividing again the observation period into two parts, we obtain clearly different trend distributions. In 1967-1996, a negative $S$ trend less than -0.001 year $^{-1}$ showed a patchy distribution at $\sigma_{\theta}=25.5-27.0 \mathrm{~kg} \mathrm{~m}^{-3}$ north of $10^{\circ} \mathrm{N}$, which corresponds mainly to the lower main halocline to the NPIW/TSM, while the trend was positive on isopycnals lighter than $25.2 \mathrm{~kg} \mathrm{~m}^{-3}$ (Fig. 4b). In 19972016, in contrast, a much stronger negative trend less than -0.005 year $^{-1}$ existed at $\sigma_{\theta}=25.0-26.2 \mathrm{~kg} \mathrm{~m}^{-3}$ north of $12^{\circ} \mathrm{N}$ corresponding mainly to the upper main halocline (Fig. 4c). The negative $S$ trend during 1967-2016 (Fig. 4a) is greatly influenced by the rapid freshening for the last 20 years (Fig. 4c). 
Fig. 3 Time series of $\mathbf{a} \theta$ and $\mathbf{b}$ $S$ averaged at $100-200 \mathrm{dbar}$ and $8-17^{\circ} \mathrm{N}$ in the $137^{\circ} \mathrm{E}$ section. Thick and thin curves denote the yearly values and values smoothed with a 10-year Gaussian filter, respectively. Horizontal bars at the top (bottom) of each panel indicate La Niña (El Niño) periods. c, $\mathbf{d}$ Time series averaged at 200-500 dbar and $30-32.67^{\circ} \mathrm{N}$, otherwise following a, b. Horizontal bars at the bottom of each panel indicate large-meander periods of the Kuroshio. e, $\mathbf{f}$ Time series averaged at 200-500 dbar and $19-28^{\circ} \mathrm{N}$, otherwise following a, $\mathbf{b}$
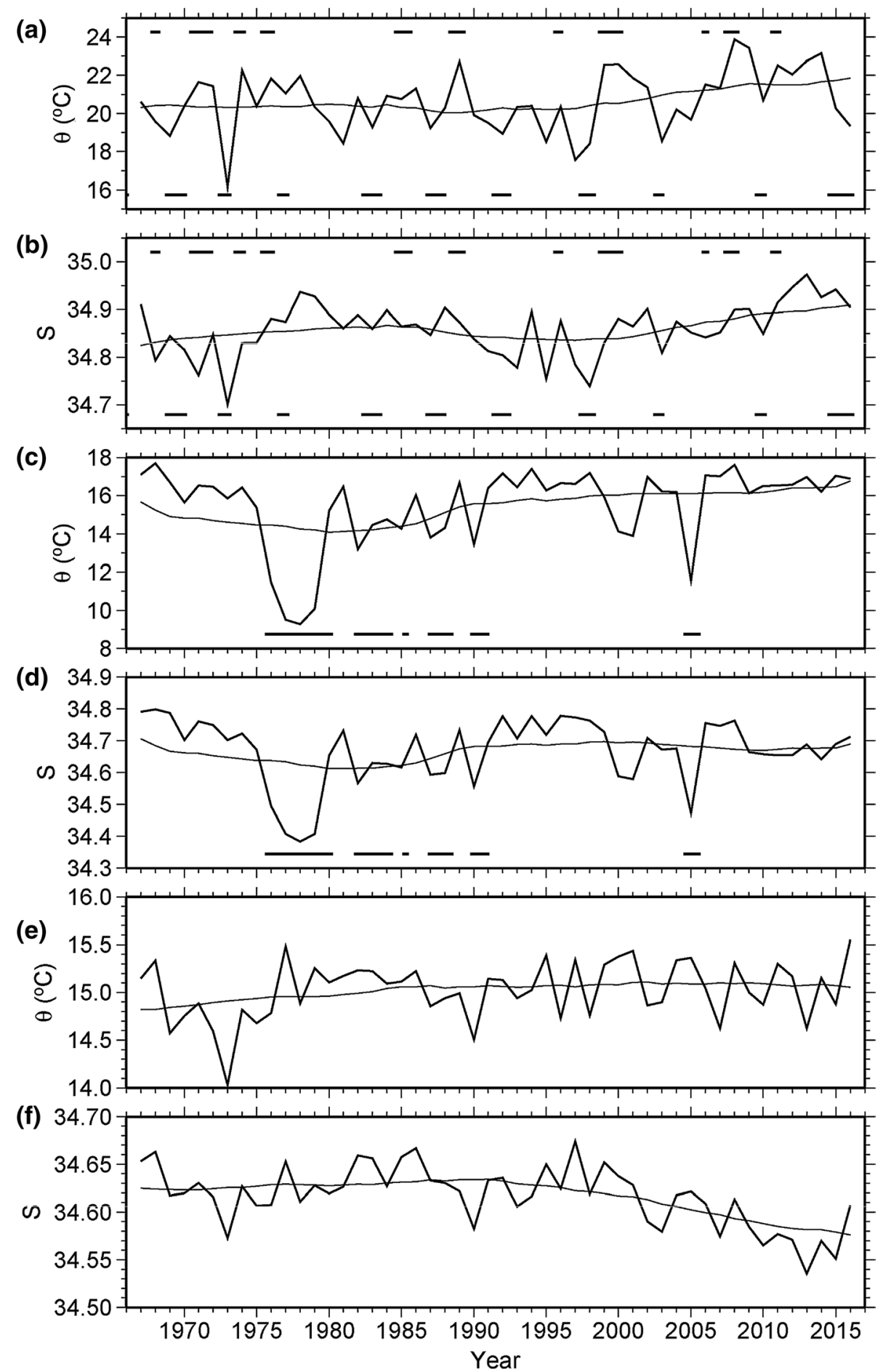

On the $\sigma_{\theta}=25.5 \mathrm{~kg} \mathrm{~m}^{-3}$ isopycnal in the subtropical gyre, where the negative trend during 1997-2016 was strongest and reached a minimum of -0.0079 year $^{-1}$ at $21^{\circ} \mathrm{N}, S$ fluctuated with a period of $\sim 15$ years from 1967 to around 1996 and then decreased significantly with a fluctuation with a period of $\sim 10$ years (Fig. $5 b$ ). $S$ on $\sigma_{\theta}=25.0 \mathrm{~kg} \mathrm{~m}^{-3}$ exhibited a similar variation with much larger decadal amplitude and led that on $25.5 \mathrm{~kg} \mathrm{~m}^{-3}$ by about 1 year, reaching pronounced maxima around 1969, 1982, 1996, 2006, and 2016 (Fig. 5a), as previously reported for the shallower layers including NPTW (Nakano et al. 2015; Nan et al. 2015). The 25.5 and $25.0 \mathrm{~kg} \mathrm{~m}^{-3}$ isopycnals correspond to the denser and lighter varieties of the subtropical mode water (STMW; Masuzawa 1969) formed in the eastern and western parts, respectively, of its formation region that extends zonally south of the Kuroshio 
Fig. 4 Linear trend (white contours with color; units year $^{-1}$ ) of $S$ with respect to $\sigma_{\theta}$ in the $137^{\circ} \mathrm{E}$ section during $\mathbf{a}$ 1967-2016, b 1967-1996, and c 1997-2016. Black contours indicate $S$ averaged in 19672016. Crosses (dots) indicate regions where the linear trend is insignificant at the $90 \%$ (95\%) confidence level
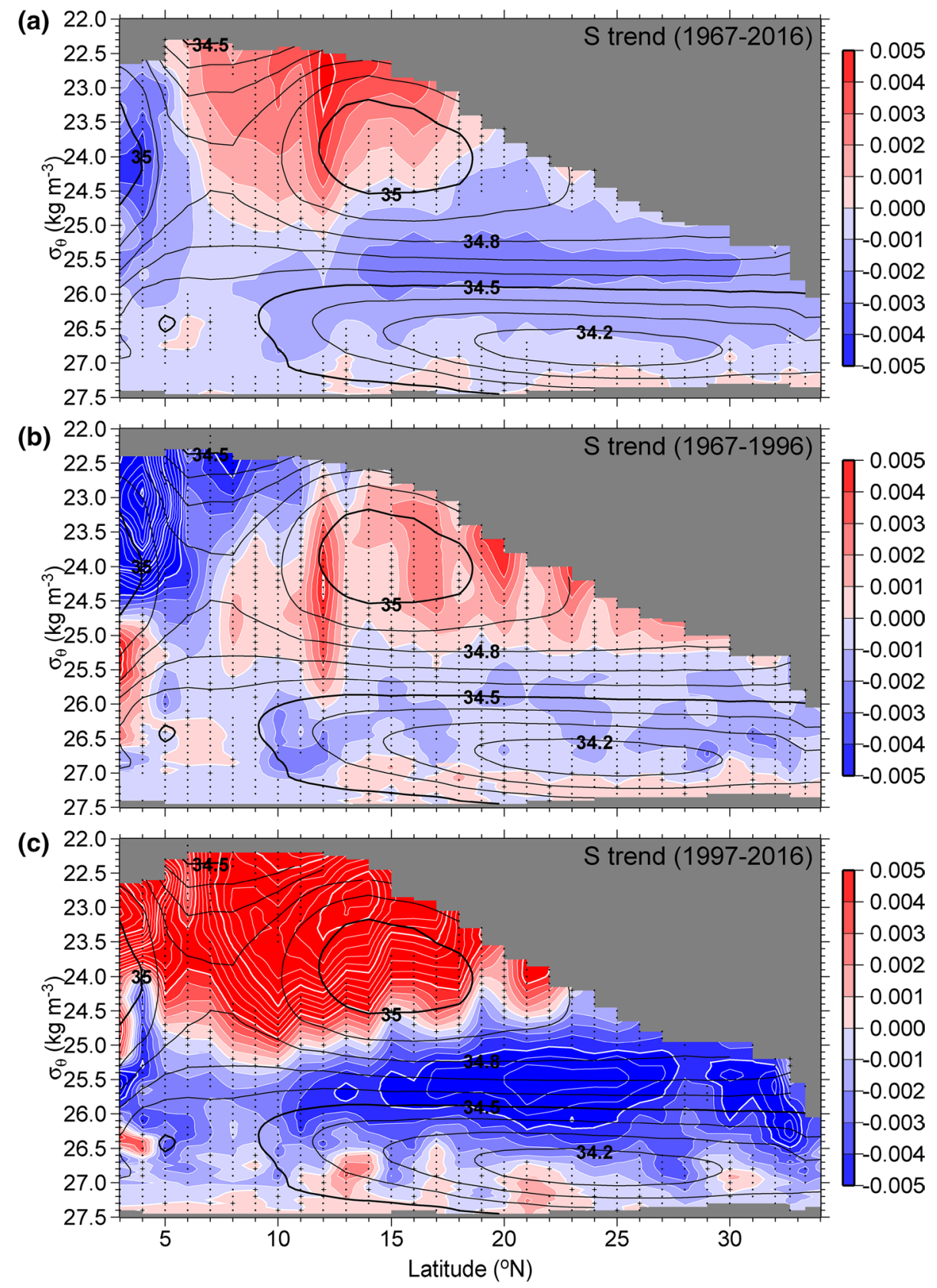

and the Kuroshio Extension (KE) and north of $28^{\circ} \mathrm{N}$ (Suga and Hanawa 1990; Oka and Suga 2003). STMW, which ventilates the upper halocline in the $137^{\circ} \mathrm{E}$ section as far south as $\sim 18^{\circ} \mathrm{N}$ (Suga et al. 1989; Oka 2009; Oka et al. 2015), seemed to contribute greatly to the observed changes and variations of subtropical $S$.

On the $\sigma_{\theta}=26.0 \mathrm{~kg} \mathrm{~m}^{-3}$ isopycnal, which corresponds to the lighter variety of the Central Mode Water (L-CMW) formed just north of the KE (Nakamura 1996; Suga et al. 1997; Oka and Suga 2005; Oka et al. 2011), $S$ showed somewhat smaller decadal variations than that on the STMW isopycnals from 1967 to around 1996 and a steady decrease after that (Fig. 5c). $S$ also decreased steadily for the last
20 years on the $\sigma_{\theta}=26.4 \mathrm{~kg} \mathrm{~m}^{-3}$ isopycnal corresponding to the denser variety of CMW north of $17^{\circ} \mathrm{N}$ and TSM south of $17^{\circ} \mathrm{N}$ (Fig. $5 \mathrm{~d}$ ). On $\sigma_{\theta}=26.8 \mathrm{~kg} \mathrm{~m}^{-3}$ corresponding to NPIW north of $17^{\circ} \mathrm{N}$ (Kaneko et al. 1998), unlike the shallower isopycnals, $S$ fluctuated on an interannual time scale and gradually decreased for the past 50 years (Fig. 5e).

\section{Relation to variations and changes in source region}

The strong freshening trend for the last 20 years existing in the subsurface layers related to STMW and L-CMW at 
Fig. 5 Time series of $S$ on isopycnals of $\sigma_{\theta}=\mathbf{a} 25.0, \mathbf{b} 25.5, \mathbf{c}$

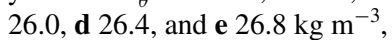
averaged at $14-16^{\circ} \mathrm{N}$ (black), $17-19^{\circ} \mathrm{N}($ red $), 20-22^{\circ} \mathrm{N}$ (yellow), $23-25^{\circ} \mathrm{N}$ (green), and $26-28^{\circ} \mathrm{N}$ (blue) in the $137^{\circ} \mathrm{E}$ section. Average during 1967-2016 was subtracted from each time series
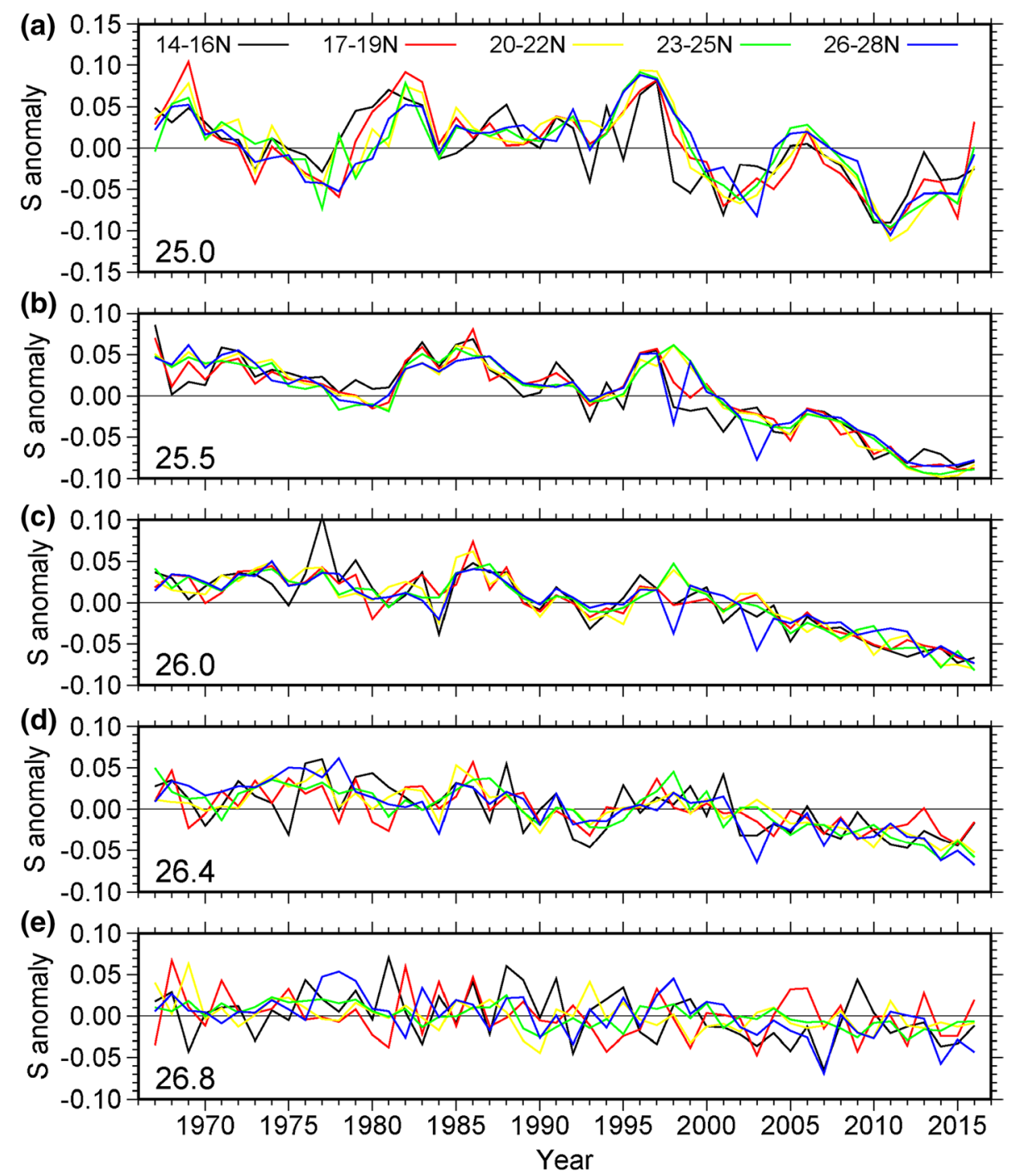

$137^{\circ} \mathrm{E}$ suggests that freshening originated in the late winter mixed layer in the KE region where these water masses are formed (e.g., Oka and Qiu 2012), as inferred by Yan et al. (2013) and Nan et al. (2015). We therefore analyzed the $144^{\circ} \mathrm{E}$ section in winter (mostly February) from 1984 through 2013. $S$ and $\theta$ at 50 dbar were averaged at stations between $30^{\circ}$ and $35^{\circ} \mathrm{N}$ because the station location differed among years. They were averaged only at those stations where $\theta$ at $300 \mathrm{dbar}$ exceeded $15{ }^{\circ} \mathrm{C}$ to ensure that the observations were conducted in the STMW formation region located south of the KE and outside cyclonic eddies. The time series was extended to 2015 by using Argo profiling float data at $30-35^{\circ} \mathrm{N}, 143-145^{\circ} \mathrm{E}$ in February of 2014 and 2015, edited as outlined in Oka et al. (2007).

The obtained winter mixed layer $S$ at $144^{\circ} \mathrm{E}$ fluctuated interannually from 1984 through 1995 and then showed a long-term decrease with a remarkable decadal variation (Fig. 6a), as recently reported for a broader KE recirculation region (Kitamura et al. 2016). $S$ reached maxima in
1995, 2005, and 2015, each of which occurred 1-2 years earlier than that observed on the STMW isopycnals at $137^{\circ} \mathrm{E}$ (Fig. 5a, b). It is highly correlated $(R=0.80-0.90)$ with a time lag of 1 year with $S$ on the $\sigma_{\theta}=25.0 \mathrm{~kg} \mathrm{~m}^{-3}$ isopycnal north of $17^{\circ} \mathrm{N}$ shown in Fig. 5a. Furthermore, its decreasing trend during 1995-2015 $\left(-0.0072\right.$ year $\left.^{-1}\right)$, together with the decreasing trend of the winter mixed layer $\theta\left(-1.4 \times 10^{-2}{ }^{\circ} \mathrm{C}\right.$ year $^{-1}$; Fig. 6a), yields an isopycnal freshening trend of about -0.008 year $^{-1}$, which is almost equal to that observed in the STMW layer at $137^{\circ} \mathrm{E} .{ }^{1}$ Such a correspondence between the $144^{\circ}$ and $137^{\circ} \mathrm{E}$ sections clearly demonstrates that the freshening

\footnotetext{
1 The trend of winter mixed layer $\theta$ during 1995-2015 was calculated without an anomalously high value in 1999 possibly owing to earlier observations around January 10 . Assuming the $\theta-S$ relation in the main pycnocline in the western subtropical gyre, the trends of winter mixed layer $\theta$ and $S$ yield those on isopycnals of about -0.009 and 0.001 year $^{-1}$, respectively.
} 
Fig. 6 a Time series of $S$ (black circles) and $\theta$ (white circles) at $50 \mathrm{dbar}$ averaged between $30^{\circ}$ and $35^{\circ} \mathrm{N}$ in the $144^{\circ} \mathrm{E}$ section. b Annual change of $S$ shown in a. The change in 1986, for example, is defined as the difference in $S$ between 1986 and 1987. c Time series of $E-P$ averaged annually at $30-35^{\circ} \mathrm{N}$, $141-150^{\circ} \mathrm{E}$ using precipitation data from CMAP (black circles) and GPCP (white circles). d

Time series of annual average of the KE index
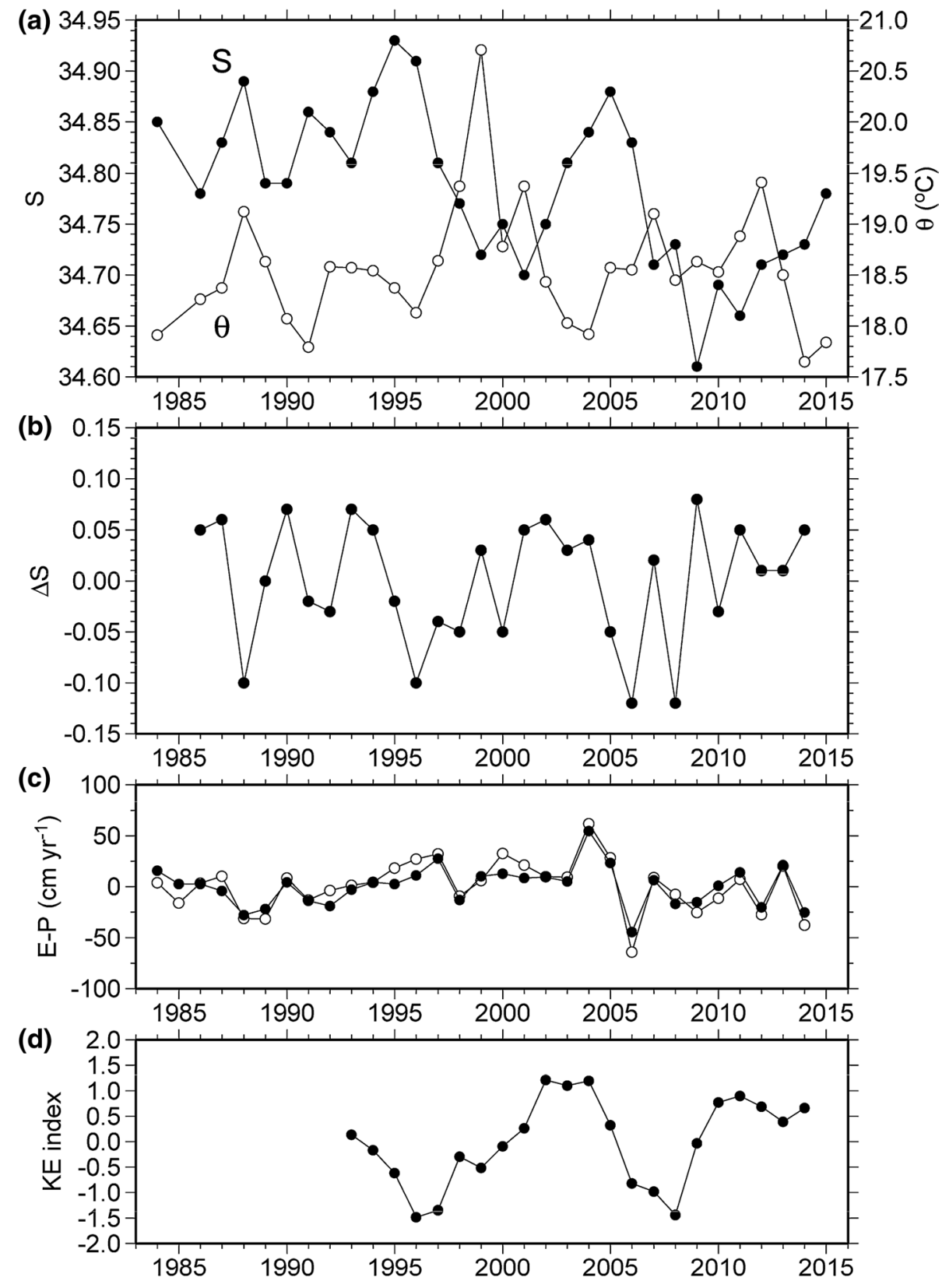

trend and decadal $S$ variation observed at $137^{\circ} \mathrm{E}$ originated in the $\mathrm{KE}$ region and was transmitted to $137^{\circ} \mathrm{E}$ 1-2 years later in association with the subduction and advection of STMW (Suga et al. 1989; Oka 2009; Oka et al. 2015).

What causes these $S$ changes and variations in the source region? Following previous studies (Sugimoto et al. 2013; Nakano et al. 2015; Nan et al. 2015; Kitamura et al. 2016), we first examined the influence of the surface freshwater flux on the decadal $S$ variation of STMW. Evaporation minus precipitation $(E-P)$ averaged annually at $30-35^{\circ} \mathrm{N}$, $141-150^{\circ} \mathrm{E}$ (Fig. 6c; the area is shown in Fig. 1a) was positively correlated with the annual change of the winter mixed layer $S$ at $144^{\circ} \mathrm{E}$ during $1986-2015$ (Fig. 6b) with $R=0.29$ and 0.19 when precipitation data from CMAP and GPCP were used, respectively.

It has been revealed during the last decade that the KE jet and its associated eddy field exhibit decadal variability (Qiu and Chen 2005; Qiu et al. 2007) in association with the Pacific Decadal Oscillation (Mantua et al. 1997) and that the winter mixed layer depth in the STMW formation region decreases (increases) during the unstable (stable) KE period (Oka et al. 2015), likely because high (low) eddy activity transports more (less) high potentialvorticity water north of the KE to the STMW formation region to hinder (facilitate) mixed layer deepening (Qiu 
and Chen 2006). Such eddy activity, at the same time, is expected to transport more (less) fresher water north of the KE to the STMW formation region to decrease (increase) the mixed layer $S$. When we look at the relation to the KE index (Fig. 6d), which was defined by Qiu et al. (2014) as the average of four KE-related parameters based on the satellite altimeter measurements, there is a connection that the winter mixed layer $S$ at $144^{\circ} \mathrm{E}$ decreased (increased) during the unstable (stable) KE period represented by a negative (positive) KE index. In fact, the annual change of the winter mixed layer $S$ during 1993-2015 is highly correlated with the annual-mean KE index $(R=0.63$; significant at the $99 \%$ confidence level). Thus, in addition to the surface freshwater flux, the KE state likely contributes to the decadal $S$ variability of STMW. A similar relation between $S$ of NPIW and the state of the downstream KE was reported by Qiu and Chen (2011).

Does either the surface freshwater flux or the KE state explain the freshening trend for the last 20 years, too? On average, $E-P$ at $30-35^{\circ} \mathrm{N}, 141-150^{\circ} \mathrm{E}$ was -9.1 $(-13.0) \mathrm{cm}_{\text {year }}{ }^{-1}$ during 1979-1994 and $3.5(4.9) \mathrm{cm} \mathrm{year}^{-1}$ during 1995-2014 with the CMAP (GPCP) precipitation data being larger during the latter period. The KE index extended back to 1977 using multidecadal hindcast simulation ${ }^{2}$ (Fig. 5b in Qiu et al. 2014) was $-0.41 \mathrm{~cm}$ during $1977-1994$ and $0.41 \mathrm{~cm}$ during $1995-2012$, indicating that the KE tended to be slightly more stable during the latter period. Thus, both the surface freshwater flux and the eddy activity acted to increase the mixed layer $S$ in the STMW formation region after 1995, compared to the prior period, and are not likely to explain the recent freshening.

\section{Summary and discussion}

Our analysis of the $137^{\circ} \mathrm{E}$ section from 1967 through 2016 demonstrated that rapid freshening on both isobars and isopycnals began in the mid-1990s and persisted for the last 20 years in the upper main thermocline/ halocline related to STMW and L-CMW in the western North Pacific subtropical gyre. The freshening trend of -0.0064 year $^{-1}$ on isobars is equivalent to a lightening trend of $\sigma_{\theta}=-0.005 \mathrm{~kg} \mathrm{~m}^{-3}$ year $^{-1}$ and has decreased the density in the main pycnocline by $0.1 \mathrm{~kg} \mathrm{~m}^{-3}$ over the last 20 years. If such an amount of density change had occurred in a 300-m-thick water column, the sea level would have risen by $3 \mathrm{~cm}$ at a rate of $1.5 \mathrm{~mm}_{\text {year }}{ }^{-1}$, contributing significantly to the baroclinic sea level rise in the western

\footnotetext{
2 The KE index here is defined using sea surface height anomaly and has a unit of $\mathrm{cm}$, while that shown in Fig. 6d is defined using four KErelated parameters and is unitless.
}

subtropical gyre during the last few decades (Suzuki and Ishii 2011). In addition to the freshening trend, significant decadal $S$ variability existed in the STMW layer, with a dominant period of $\sim 15$ years before the mid-1990s and $\sim 10$ years after that, as previously reported for the shallower layers including NPTW in the $137^{\circ} \mathrm{E}$ section (Nakano et al. 2015; Nan et al. 2015). Such large variability implies that the estimation of trends from relatively short time series like Argo (Roemmich et al. 2001) can lead to significant over/underestimation. The analysis of the $144^{\circ} \mathrm{E}$ section during 1984-2015 revealed that the freshening trend and decadal $S$ variability observed at $137^{\circ} \mathrm{E}$ originated in the winter mixed layer in the $\mathrm{KE}$ region and was transmitted to $137^{\circ} \mathrm{E} 1-2$ years later in association with the subduction and advection of STMW.

The mechanism of these changes and variations in the source region was further investigated. In addition to the surface freshwater flux in the KE region pointed out by previous studies, the KE state likely contributes to the decadal $S$ variability. Specifically, high (low) eddy activity during the unstable (stable) KE period, which lags the warm (cool) phase of the Pacific Decadal Oscillation by 3-4 years (Qiu et al. 2007), transports more (less) fresher water north of the KE to the STMW formation region to decrease (increase) $S$ of the deep winter mixed layer. The freshening trend for the last 20 years, however, cannot be explained by interdecadal change in either the surface freshwater flux or the KE state. This problem is left for a future study.

A noteworthy feature found in Fig. 5 is the coherent $S$ variations among latitudes and isopycnals. First, decadal variations on each isopycnal in the STMW density range $\left(\sigma_{\theta}=25.0\right.$ and $\left.25.5 \mathrm{~kg} \mathrm{~m}^{-3}\right)$ occurred almost simultaneously across the subtropical gyre between $14^{\circ}$ and $28^{\circ} \mathrm{N}$. If we assume streamlines on these isopycnals based on climatological $S$ and $T$, a water parcel reaching a southern station of the $137^{\circ} \mathrm{E}$ section along an outer path from its outcrop region should take a much longer time than that reaching a northern station along an inner path (Fig. 3 in Bingham et al. 2002; for example, a water parcel on $\sigma_{\theta}=25.0 \mathrm{~kg} \mathrm{~m}^{-3}$ reaching $24^{\circ} \mathrm{N}$ takes 4.3 years, while that reaching $16^{\circ} \mathrm{N}$ takes 11.4 years). In the real ocean, eddy mixing seems to spread rapidly the isopycnal $\theta / S$ anomalies, or spiciness anomalies, southward once STMW is subducted to the permanent pycnocline. This is supported by the recent observations along the $149^{\circ} \mathrm{E}$ meridian, where radiocesium released from the Fukushima Dai-ichi nuclear power plant in March 2011 spread as far south as $20^{\circ} \mathrm{N}$ in January 2012, only 10 months after the accident (Kumamoto et al. 2014). Secondly, the rapid freshening initiated almost simultaneously around 1996 between $\sigma_{\theta}=25.0$ and $26.4 \mathrm{~kg} \mathrm{~m}^{-3}$ (Fig. 5a-d) despite our expectation that CMW subducted from the region north of KE takes an even longer time (more than 16 years according to Fig. 3 in Bingham 
et al. 2002) to reach the $137^{\circ} \mathrm{E}$ section if we assume its large-scale circulation (Bingham et al. 2002; Suga et al. 2004; Oka et al. 2011). Since decadal variations were small on $\sigma_{\theta}=26.0$ and $26.4 \mathrm{~kg} \mathrm{~m}^{-3}$, the diapycnal-mixing mechanism is less likely. A possible explanation is that the southward, mesoscale subduction of CMW across the KE (Oka et al. 2009, 2014) occurs so vigorously that the CMW layer in the $137^{\circ} \mathrm{E}$ section quickly responded to the surface freshening north of the KE. Another possibility is that the area of surface freshening spread southward year by year, from the region north of the KE to that south of it.

Another remaining problem is that $\theta$ in the winter mixed layer at $144^{\circ} \mathrm{E}$ was negatively correlated with $S(R=-0.35$ during 1984-2015; Fig. 6a) in spite of our expectation that high (low) eddy activity during the unstable (stable) KE period transports more (less) not only fresher but also colder water north of the KE to the STMW formation region to decrease (increase) both $S$ and $\theta$. Actually, Sugimoto and Kako (2016) recently analyzed historical $T$ profiles during 1968-2014 to claim that after $\sim 1990$ the winter mixed layer $\theta$ in the STMW formation region increases (decreases) during the unstable (stable) KE period, mainly as a result of a weaker (stronger) cooling effect of entrainment in association with the winter mixed layer shallowing (deepening). Since not only $\theta$ but also $S$ decreases downward below STMW (e.g., Hanawa and Talley 2001), the weaker (stronger) entrainment effect during the unstable (stable) KE period acts to increase (decrease) both the mixed layer $S$ and $\theta$, in the opposite way to the high (low) eddy activity. The opposite effects of entrainment and eddy activity to the decadal $S$ and $\theta$ variations in the STMW formation region need to be quantified for further understanding of the mechanism.

Acknowledgements The authors are grateful to the past and present captains and crews of R/Vs Ryofu maru and Keifu maru and staff of the Marine Division (and the former Oceanographical Division), Japan Meteorological Agency, for their laudable efforts in long-term observations. They also thank Katsuro Katsumata, Shinya Kouketsu, Takashi Sakamoto, Shusaku Sugimoto, Tatsuro Suzuki, Hiroyuki Yoritaka, participants at the "Research Meeting on Air-Sea Interaction" in 2016 held as a part of the Collaborative Research Program of the Institute for Space-Earth Environmental Research, Nagoya University, and anonymous reviewers for helpful comments on the manuscript. E. O. and T. S. acknowledge support by the Japan Society for the Promotion of Science (JSPS) through Grant 21340133 and 25287118. T. S. also acknowledges support by JSPS through Grant 15H02129. S. K. is a research fellow of JSPS and is supported by JSPS through 15J05210.

Open Access This article is distributed under the terms of the Creative Commons Attribution 4.0 International License (http://creativecommons.org/licenses/by/4.0/), which permits unrestricted use, distribution, and reproduction in any medium, provided you give appropriate credit to the original author(s) and the source, provide a link to the Creative Commons license, and indicate if changes were made.

\section{References}

Adler RF et al (2003) The version-2 global precipitation climatology project (GPCP) monthly precipitation analysis (1979-present). $\mathbf{J}$ Hydrometeor 4:1147-1167

Bingham FM, Suga T, Hanawa K (2002) Origin of waters observed along $137^{\circ}$ E. J Geophys Res 107:3073. doi:10.1029/200 0JC000722

Boyer TP, Antonov JI, Levitus S, Locarnini R (2005) Linear trends of salinity for the world ocean, 1955-1998. Geophys Res Lett 32:L01604. doi:10.1029/2004GL021791

Cannon GA (1966) Tropical waters in the western Pacific Oceans, August-September 1957. Deep-Sea Res Oceanogr Abstr 13:1139-1148

Durack PJ, Wijffels SE (2010) Fifty-year trend in global ocean salinities and their relationship to broad-scale warming. J Clim 23:4342-4362. doi:10.1175/2010JCLI3377.1

Hanawa K, Talley LD (2001) Mode waters. In: Church J et al (eds) Ocean circulation and climate. Academic, London, pp 373-386

Hosoda S, Suga T, Shikama N, Mizuno K (2009) Global surface layer salinity change detected by ARGO and its implication for hydrological cycle intensification. J Oceanogr 65:579-586. doi:10.1007/s10872-009-0049-1

Huffman GJ et al (1997) The Global Precipitation Climatology Project (GPCP) combined precipitation dataset. Bull Am Meteorol Soc 78:5-20

Japan Maritime Safety Agency (1986-1996) Data report of hydrographic observations-series of WESTPAC, Nos. 1-11

Japan Meteorological Agency (1970) Manual on oceanographic observations. p 427 (in Japanese)

Kaneko I, Takatsuki Y, Kamiya H, Kawae S (1998) Water property and current distributions along the WHP-P9 section $\left(137^{\circ}-142^{\circ} \mathrm{E}\right)$ in the western North Pacific. J Geophys Res 103:12959-12984

Katsura S, Oka E, Qiu B, Schneider N (2013) Formation and subduction of North Pacific tropical water and their interannual variability. J Phys Oceanogr 43:2400-2415

Kawabe M (1995) Variations of current path, velocity, and volume transport of the Kuroshio in relation with the large meander. $\mathrm{J}$ Phys Oceanogr 25:3103-3117

Kitamura T, Nakano T, Sugimoto S (2016) Decadal variations in mixed layer salinity in the Kuroshio Extension recirculation gyre region: influence of precipitation during the warm season. $\mathrm{J}$ Oceanogr 72:167-175

Kumamoto Y, Aoyama M, Hamajima Y, Aono T, Kouketsu S, Murata A, Kawano T (2014) Southward spreading of the Fukushimaderived radiocaesium across the Kuroshio Extension in the North Pacific. Sci Rep 4:4276. doi:10.1038/srep04276

Lukas R (2001) Freshening of the upper thermocline in the North Pacific subtropical gyre associated with decadal changes of rainfall. Geophys Res Lett 28:3485-3488

Mantua NJ, Hare SR, Zhang Y, Wallace JM, Francis RC (1997) A Pacific interdecadal climate oscillation with impacts on salmon production. Bull Am Meteorol Soc 78:1069-1079

Masuzawa J (1967) An oceanographic section from Japan to New Guinea at $137^{\circ} \mathrm{E}$ in January 1967 . Oceanogr Mag 19:95-118

Masuzawa J (1969) Subtropical mode water. Deep-Sea Res 16:463-472

Masuzawa J, Nagasaka K (1975) The $137^{\circ} \mathrm{E}$ oceanographic section. J Mar Res 33(Suppl):109-116

Nakamura H (1996) A pycnostad on the bottom of the ventilated portion in the central subtropical North Pacific: its distribution and formation. J Oceanogr 52:171-188

Nakano T, Kaneko I, Soga T, Tsujino H, Yasuda T, Ishizaki H, Kamachi M (2007) Mid-depth freshening in the North Pacific subtropical gyre observed along the JMA repeat and WOCE 
hydrographic sections. Geophys Res Lett 34:L23608. doi:10.1 029/2007GL031433

Nakano T, Kitamura T, Sugimoto S, Suga T, Kamachi M (2015) Long-term variations of North Pacific tropical water along the $137^{\circ} \mathrm{E}$ repeat hydrographic section. J Oceanogr 71:229-238

Nan F, Yu F, Wang R, Si G (2015) Ocean salinity changes in the northwest Pacific subtropical gyre: the quasi-decadal oscillation and the freshening trend. J Geophys Res 120:2179-2192

Oka E (2009) Seasonal and interannual variation of North Pacific subtropical mode water in 2003-2006. J Oceanogr 65:151-164

Oka E, Qiu B (2012) Progress of North Pacific mode water research in the past decade. J Oceanogr 68:5-20

Oka E, Suga T (2003) Formation region of North Pacific subtropical mode water in the late winter of 2003. Geophys Res Lett 30:2205. doi:10.1029/2003GL018581

Oka E, Suga T (2005) Differential formation and circulation of North Pacific Central Mode Water. J Phys Oceanogr 35:1997-2011

Oka E, Talley LD, Suga T (2007) Temporal variability of winter mixed layer in the mid- to high-latitude North Pacific. J Oceanogr 63:293-307

Oka E, Toyama K, Suga T (2009) Subduction of North Pacific central mode water associated with subsurface mesoscale eddy. Geophys Res Lett 36:L08607. doi:10.1029/2009GL037540

Oka E, Kouketsu S, Toyama K, Uehara K, Kobayashi T, Hosoda S, Suga T (2011) Formation and subduction of Central Mode Water based on profiling float data, 2003-08. J Phys Oceanogr 41:113-129

Oka E, Uehara K, Nakano T, Suga T, Yanagimoto D, Kouketsu S, Itoh S, Katsura S, Talley LD (2014) Synoptic observation of Central Mode Water in its formation region in spring 2003. J Oceanogr 70:521-534

Oka E, Qiu B, Takatani Y, Enyo K, Sasano D, Kosugi N, Ishii M, Nakano T, Suga T (2015) Decadal variability of subtropical mode water subduction and its impact on biogeochemistry. J Oceanogr 71:389-400

Qiu B, Chen S (2005) Variability of the Kuroshio Extension jet, recirculation gyre and mesoscale eddies on decadal timescales. J Phys Oceanogr 35:2090-2103

Qiu B, Chen S (2006) Decadal variability in the formation of the North Pacific subtropical mode water: oceanic versus atmospheric control. J Phys Oceanogr 36:1365-1380

Qiu B, Chen S (2011) Effect of decadal Kuroshio Extension jet and eddy variability on the modification of North Pacific Intermediate Water. J Phys Oceanogr 41:503-515

Qiu B, Chen S (2012) Multidecadal sea level and gyre circulation variability in the northwestern tropical Pacific Ocean. J Phys Oceanogr 42:193-206

Qiu B, Joyce TM (1992) Interannual variability in the mid- and lowlatitude western North Pacific. J Phys Oceanogr 22:1062-1079

Qiu B, Chen S, Hacker P (2007) Effect of mesoscale eddies on subtropical mode water variability from the Kuroshio Extension System Study (KESS). J Phys Oceanogr 37:982-1000

Qiu B, Chen S, Schneider N, Taguchi B (2014) A coupled decadal prediction of the dynamic state of the Kuroshio Extension system. J Clim 27:1751-1764

Reid JL Jr (1965) Intermediate waters of the Pacific Ocean. Johns Hopkins Oceanography Studies, vol 2. Johns Hopkins University Press, Baltimore, $\mathrm{p} 85$

Ren L, Riser SC (2010) Observations of decadal time scale salinity changes in the subtropical thermocline of the North Pacific Ocean. Deep Sea Res Part II 57:1161-1170

Rhein M, Rintoula S, Aoki S, Campos E, Chambers D, Feely R, Gulev S, Johnson G, Josey S, Kostianoy A, Mauritzen C, Roemmich D, Talley L, Wang F (2013) Observations: ocean. In: Stocker TF, Qin D, Plattner GK, Tignor M, Allen SK, Boschung J, Nauels A, Xia Y, Bex V, Midgley PM (eds) Climate change 2013: the physical science basis. Contribution of working group I to the fifth assessment report of the intergovernmental panel on climate change. Cambridge University Press, Cambridge

Roemmich D, Boebel O, Desaubies Y, Freeland H, King B, LeTraon PY, Molinari R, Owens WB, Riser S, Send U, Takeuchi K, Wijffels S (2001) Argo: the global array of profiling floats. In: Koblinsky CJ, Smith NR (eds) Observing the oceans in the 21st century. GODAE Project Office, Bureau of Meteorology, Melbourne, pp 248-258

Saiki M (1987) Interannual variation of the subtropical gyre in the western North Pacific. Umi to Sora 63:113-125 (in Japanese with English abstract)

Shuto K (1996) Interannual variations of water temperature and salinity along the $137^{\circ} \mathrm{E}$ meridian. J Oceanogr 52:575-595

Suga T, Hanawa K (1990) The mixed layer climatology in the northwestern part of the North Pacific subtropical gyre and the formation area of subtropical mode water. J Mar Res 48:543-566

Suga T, Hanawa K, Toba Y (1989) Subtropical mode water in the $137^{\circ}$ E section. J Phys Oceanogr 19:1605-1618

Suga T, Takei Y, Hanawa K (1997) Thermostad distribution in the North Pacific subtropical gyre: the central mode water and the subtropical mode water. J Phys Oceanogr 27:140-152

Suga T, Kato A, Hanawa K (2000) North Pacific Tropical Water: its climatology and temporal changes associated with the climate regime shift in the 1970s. Prog Oceanogr 47:223-256

Suga T, Motoki K, Aoki Y, Macdonald AM (2004) The North Pacific climatology of winter mixed layer and mode waters. J Phys Oceanogr 34:3-22

Sugimoto S, Kako SI (2016) Decadal variation in winter mixed layer depth south of the Kuroshio Extension and its influence on winter mixed layer temperature. J Climate 29:1237-1252

Sugimoto S, Takahashi N, Hanawa K (2013) Marked freshening of North Pacific subtropical mode water in 2009 and 2010: influence of freshwater supply in the 2008 warm season. Geophys Res Lett 40:3102-3105

Suzuki T, Ishii M (2011) Long-term regional sea level changes due to variations in water mass density during the period 1981-2007. Geophys Res Lett 38:L21604. doi:10.1029/2011GL049326

Talley LD, Pickard GL, Emery WJ, Swift JH (2011) Descriptive physical oceanography: an introduction. Academic, New York, p 560

Tsuchiya M (1968) Upper waters of the intertropical Pacific Ocean. Johns Hopkins Oceanography Studies, vol 4. Johns Hopkins University Press, Baltimore, p 50

Usui N, Tsujino H, Nakano H, Matsumoto S (2013) Long-term variability of the Kuroshio path south of Japan. J Oceanogr 69:647-670

Wong APS, Bindoff NL, Church JA (1999) Large-scale freshening of intermediate waters in the Pacific and Indian Oceans. Nature 400:440-443

Wong APS, Bindoff NL, Church JA (2001) Freshwater and heat changes in the north and south Pacific Oceans between the 1960s and 1985-94. J Clim 14:1613-1633

Xie P, Arkin PA (1996) Analyses of global monthly precipitation using gauge observations, satellite estimates, and numerical model predictions. J Clim 9:840-858

Xie P, Arkin PA (1997) A 17-year monthly analysis based on gauge observations, satellite estimates and numerical model outputs. Bull Am Meteorol Soc 78:2539-2558

Yan YF, Chassignet EP, Qi YQ, Dewar WK (2013) Freshening of subsurface waters in the northwest Pacific subtropical gyre: observations and dynamics. J Phys Oceanogr 43:2733-2751

Yu L, Weller RA (2007) Objectively Analyzed air-sea heat Fluxes (OAFlux) for the global ocean. Bull Am Meteorol Soc 88:527-539

Yu L, Jin X, Weller R (2008) Multidecade global flux datasets from the Objectively Analyzed Air-sea Fluxes (OAFlux) Project: 
latent and sensible heat fluxes, ocean evaporation, and related surface meteorological variables. OAFlux Proj technical report OA-2008-01
Yuan X, Talley LD (1992) Shallow salinity minima in the North Pacific. J Phys Oceanogr 22:1302-1316 